\title{
Article \\ Aquatic Hyphomycete Taxonomic Relatedness Translates into Lower Genetic Divergence of the Nitrate Reductase Gene
}

\author{
Joana Mariz ${ }^{1,2} \mathbb{D}$, Ricardo Franco-Duarte ${ }^{1,2} \mathbb{D}$, Fernanda Cássio ${ }^{1,2}$, Cláudia Pascoal ${ }^{1,2, \dagger}$ \\ and Isabel Fernandes $1,2, *,+$ (iD \\ 1 Centre of Molecular and Environmental Biology (CBMA), Department of Biology, University of Minho, \\ 4710-057 Braga, Portugal; joanavmariz@gmail.com (J.M.); ricardofilipeduarte@bio.uminho.pt (R.F.-D.); \\ fcassio@bio.uminho.pt (F.C.); cpascoal@bio.uminho.pt (C.P.) \\ 2 Institute of Science and Innovation for Bio-Sustainability (IB-S), University of Minho, 4710-057 Braga, Portugal \\ * Correspondence: isabelrodriguesfernandes@bio.uminho.pt \\ + Co-last authors.
}

Citation: Mariz, J.; Franco-Duarte, R.; Cássio, F.; Pascoal, C.; Fernandes, I. Aquatic Hyphomycete Taxonomic Relatedness Translates into Lower Genetic Divergence of the Nitrate Reductase Gene. J. Fungi 2021, 7, 1066. https://doi.org/10.3390/jof7121066

Academic Editors: Pierre-Emmanuel Courty and Laurent Dufossé

Received: 3 November 2021

Accepted: 6 December 2021

Published: 11 December 2021

Publisher's Note: MDPI stays neutral with regard to jurisdictional claims in published maps and institutional affiliations.

Copyright: (c) 2021 by the authors. Licensee MDPI, Basel, Switzerland. This article is an open access article distributed under the terms and conditions of the Creative Commons Attribution (CC BY) license (https:// creativecommons.org/licenses/by/ $4.0 /)$.

\begin{abstract}
Aquatic hyphomycetes are key microbial decomposers in freshwater that are capable of producing extracellular enzymes targeting complex molecules of leaf litter, thus, being crucial to nutrient cycling in these ecosystems. These fungi are also able to assimilate nutrients (e.g., nitrogen) from stream water, immobilizing these nutrients in the decomposing leaf litter and increasing its nutritional value for higher trophic levels. Evaluating the aquatic hyphomycete functional genetic diversity is, thus, pivotal to understanding the potential impacts of biodiversity loss on nutrient cycling in freshwater. In this work, the inter- and intraspecific taxonomic (ITS1-5.8S-ITS2 region) and functional (nitrate reductase gene) diversity of 40 aquatic hyphomycete strains, belonging to 23 species, was evaluated. A positive correlation was found between the taxonomic and nitrate reductase gene divergences. Interestingly, some cases challenged this trend: Dactylella cylindrospora (Orbiliomycetes) and Thelonectria rubi (Sordariomycetes), which were phylogenetically identical but highly divergent regarding the nitrate reductase gene; and Collembolispora barbata (incertae sedis) and Tetracladium apiense (Leotiomycetes), which exhibited moderate taxonomic divergence but no divergence in the nitrate reductase gene. Additionally, Tricladium chaetocladium (Leotiomycetes) strains were phylogenetically identical but displayed a degree of nitrate reductase gene divergence above the average for the interspecific level. Overall, both inter- and intraspecific functional diversity were observed among aquatic hyphomycetes.
\end{abstract}

Keywords: aquatic hyphomycetes; biodiversity; enzymes; functional gene; freshwater ecosystems; leaf litter decomposition

\section{Introduction}

Small forested streams make up the majority of river basins' water courses in temperate regions [1]. The main sources of energy and carbon (C) in these ecosystems are allochthonous inputs of non-living organic $C$, particularly leaf litter from riparian vegetation [2,3]. The decomposition of plant litter is mostly driven by microorganisms and invertebrates [4]. Among microbial decomposers, aquatic fungi have been recognized to play a leading role in this process, exhibiting high biomass and production rates [5,6].

Within fungi, a polyphyletic group known as aquatic hyphomycetes stands out as the dominant intermediate in organic matter decomposition and nutrient recycling in headwater stream ecosystems [6-8]. Among other features, aquatic hyphomycetes owe their competitive advantage to the ability to produce and secrete a vast array of extracellular degradative enzymes that break down plant cell wall polysaccharides, such as cellulose, hemicellulose, pectin and lignin $[9,10]$.

Nitrogen (N) and phosphorus (P) are known to limit microbial decomposers' activity, as the demand for these nutrients is usually higher than their availability in streams [1]. 
Nutrient uptake and assimilation seem to help communities resolve this mismatch [4, 11]. In fact, several studies observed a faster decomposition of $\mathrm{N}$ - and P-rich organic substrates [12-15] as well as in $\mathrm{N}$ - and P-enriched stream waters $[13,15,16]$.

In freshwater ecosystems, $\mathrm{N}$ can be provided from natural (e.g., the atmosphere, soils and vegetation) and anthropogenic (e.g., fertilizers, sewage and atmospheric depositions) sources and occurring in different chemical states, such as ammonium $\left(\mathrm{NH}_{4}{ }^{+}\right)$, nitrate $\left(\mathrm{NO}_{3}{ }^{-}\right)$and nitrite $\left(\mathrm{NO}_{2}\right)[1,17]$. Microbial decomposers are major drivers of $\mathrm{N}$ assimilation, usually selecting nitrate as the favoured $\mathrm{N}$ source $[18,19]$. The assimilation process requires two enzymes: nitrate and nitrite reductase. Nitrate reductase is responsible for initiating the metabolic process through the conversion of nitrate to nitrite, and this is necessary for cellular nitrate accumulation in nitrate-assimilating fungi $[20,21]$. Nitrite reductase mediates the reduction of nitrite to ammonium $[20,21]$. To the best of our knowledge, only one study showed the presence of nitrate reductase genes in few species of the aquatic hyphomycete genus Tetracladium [22].

Several studies observed a positive relationship between aquatic hyphomycete richness and leaf litter decomposition in streams (e.g., [23-25]), although considerable functional redundancy among fungi has been recognized [26-28]. The role of intraspecific [25] or genetic diversity [28] has received considerably less attention, even with the known relevance of functional traits in maintaining ecosystem processes, particularly under stress [25].

Genetic diversity ensures diverse metabolic pathways and might be more relevant than species richness per se for the functioning of microbial communities, particularly under ongoing environmental changes $[25,29]$. Studies on aquatic fungal genetic diversity have been mostly linked to their taxonomy (e.g., [30-32]) with only a limited number of studies addressing functional genetic diversity (e.g., [33,34]). Solé et al. [33] focused on the influence of stream pollution (by metals and xenobiotic organic compounds) on the expression and activity of fungal laccases, which are multicopper oxidase enzymes with distinct functions, including the degradation of lignin compounds. This study found that the aquatic hyphomycete Clavariopsis aquatica was able to express five putative laccase genes, including lcc4, which is likely to encode an extracellular laccase potentially involved in lignocellulose breakdown and the detoxification of plant-related phenolics in decaying leaves and woody debris during fungal colonization [33].

More recently, the functional diversity of several Tetracladium species was assessed, through the detection of carbohydrate active enzymes (e.g., pectate lyase) and secondary metabolites [34]. The results of this study show that Tetracladium are well-suited to digest pectate and pectin. Considering the ecological importance of aquatic hyphomycetes for the detrital food-webs in freshwater, knowledge on their functional genetic diversity is crucial to understand the potential impacts of biodiversity loss on nutrient cycling.

The aim of this study was to detect and analyse a functional gene involved in $\mathrm{N}$-cycling from several aquatic hyphomycete species. To that end, we analysed the inter- and intraspecific taxonomic (ITS1-5.8S-ITS2 region) and functional (nitrate reductase gene euknr) diversity of 40 aquatic hyphomycete strains belonging to 23 species, using a combination of experimental and in silico approaches. We hypothesized that species with closer taxonomic similarities would exhibit lower functional genetic divergence in the nitrate reductase gene and, consequently, a positive relationship between taxonomic and functional diversity. We expected this divergence to be lower at the intraspecific level than between species (the interspecific level) due to the closer relatedness.

\section{Materials and Methods}

\subsection{Fungal Strains, Growth Conditions and DNA Extraction}

We used a total of 40 strains of aquatic hyphomycetes from 23 species. Sequences of six strains were obtained using in silico approaches (see the section In Silico Assays) and sequences of another four strains were retrieved from Gorfer et al., 2011 [22]. The remaining strains used belonged to the culture collection of the Centre of Molecular and Environmental Biology (CBMA), University of Minho (Table 1). Fungi were grown for 
15-30 days in $2 \%$ malt extract agar media and kept in the dark at $15^{\circ} \mathrm{C}$. DNA extraction was performed using UltraClean ${ }^{\circledR}$ Soil DNA Isolation Kit (MO BIO Laboratories, Solana Beach, CA, USA) according to the manufacturer's instructions, except for the final elution step, where $30 \mu \mathrm{L}$ of Solution S5 were added to increase the final DNA concentration. DNA was stored at $-80^{\circ} \mathrm{C}$ until used.

\subsection{Fungal Identification}

For morphological identification, agar plugs from the fungal colonies were placed in a $50 \mathrm{~mL}$ Erlenmeyer flask with sterile deionised water (renewed weekly) and kept in an orbital shaker $(120 \mathrm{rpm})$ at $15{ }^{\circ} \mathrm{C}$. Every other day, $200 \mu \mathrm{L}$ of water suspension was collected and placed on a microscope slide. After drying, a drop of $0.1 \%$ cotton blue in lactic acid was added to stain the spores for identification under a light microscope [35]. Images were captured using a Leica ICC50 W light microscope (Leica Microsystems, Carnaxide, Portugal) at $400 \times$ magnification (Figure S1).

For cases of lack of sporulation, addition of sterilized alder leaf fragments and/or aeration through air pumps [35] were done (flasks kept at $20^{\circ} \mathrm{C}$ ). For molecular identification, the ITS1-5.8S-ITS2 region of the rDNA of each fungal strain was amplified by PCR as follows: $12.5 \mu \mathrm{L}$ of Accuzyme mix $(2 \times)$ (Bioline, London, UK), $0.4 \mu \mathrm{M}$ of each primer (ITS1F: 5'-CTTGGTCATTTAGAGGAAGTAA-3' [36] and ITS4: 5'-TCCTCCGCTTATTGATATGC$3^{\prime}$ [37]) and $2 \mu \mathrm{L}$ of DNA in a final volume of $25 \mu \mathrm{L}$.

The amplification programme was performed in an iCycler Thermal Cycler (BioRad, Hercules, CA, USA), with an initial denaturation at $94^{\circ} \mathrm{C}$ for $2 \mathrm{~min}, 30$ cycles of denaturation $\left(94{ }^{\circ} \mathrm{C}, 45 \mathrm{~s}\right)$, annealing $\left(56^{\circ} \mathrm{C}, 45 \mathrm{~s}\right)$ and extension $\left(72{ }^{\circ} \mathrm{C}, 90 \mathrm{~s}\right)$ and a final extension at $72{ }^{\circ} \mathrm{C}$ for $10 \mathrm{~min}$ (adapted from [38]). Negative controls with no DNA template were included in each batch. The PCR products were run on a $2 \%$ agarose gel with $3 \%$ GreenSafe Premium (NZYtech, Lisbon, Portugal) at $80 \mathrm{~V}$ for $75 \mathrm{~min}$. The PCR products were purified using Invitrogen's PureLink ${ }^{\circledR}$ PCR Purification Kit (Invitrogen Life Technologies, Carlsbad, CA, USA) according to the manufacturer's instructions, with the exception of final elution where $30 \mu \mathrm{L}$ where used (instead of the recommended $50 \mu \mathrm{L}$ ) to increase the final DNA concentration.

The DNA concentration was measured using a Nanodrop 1000 Spectrophotometer (Thermo Scientific, Wilmington, DE, USA). DNA sequencing was performed at STABVIDA (Caparica, Portugal) using the primers ITS1F and ITS4. The sequences were trimmed and aligned against each other in order to establish the consensus ITS sequence for each fungal strain and subjected to an individual Basic Local Alignment Search Tool (BLAST; https: / / BLAST.ncbi.nlm.nih.gov / BLAST.cgi; accessed on 29 November 2019). The parameters for species name attribution were met when ITS sequences presented $\geq 85 \%$ of query coverage and $98-100 \%$ of sequence similarity within the results of the BLAST search [39]. The DNA sequences were submitted to Genbank (Table 1). 


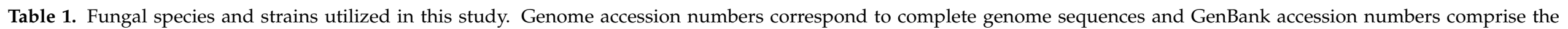

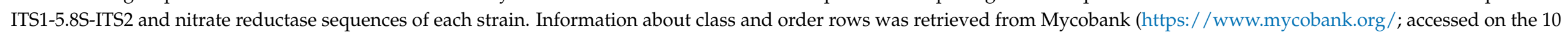
September 2021). n/a, not attributed. s/m, Sequence available in the Supplementary Material Table S1.

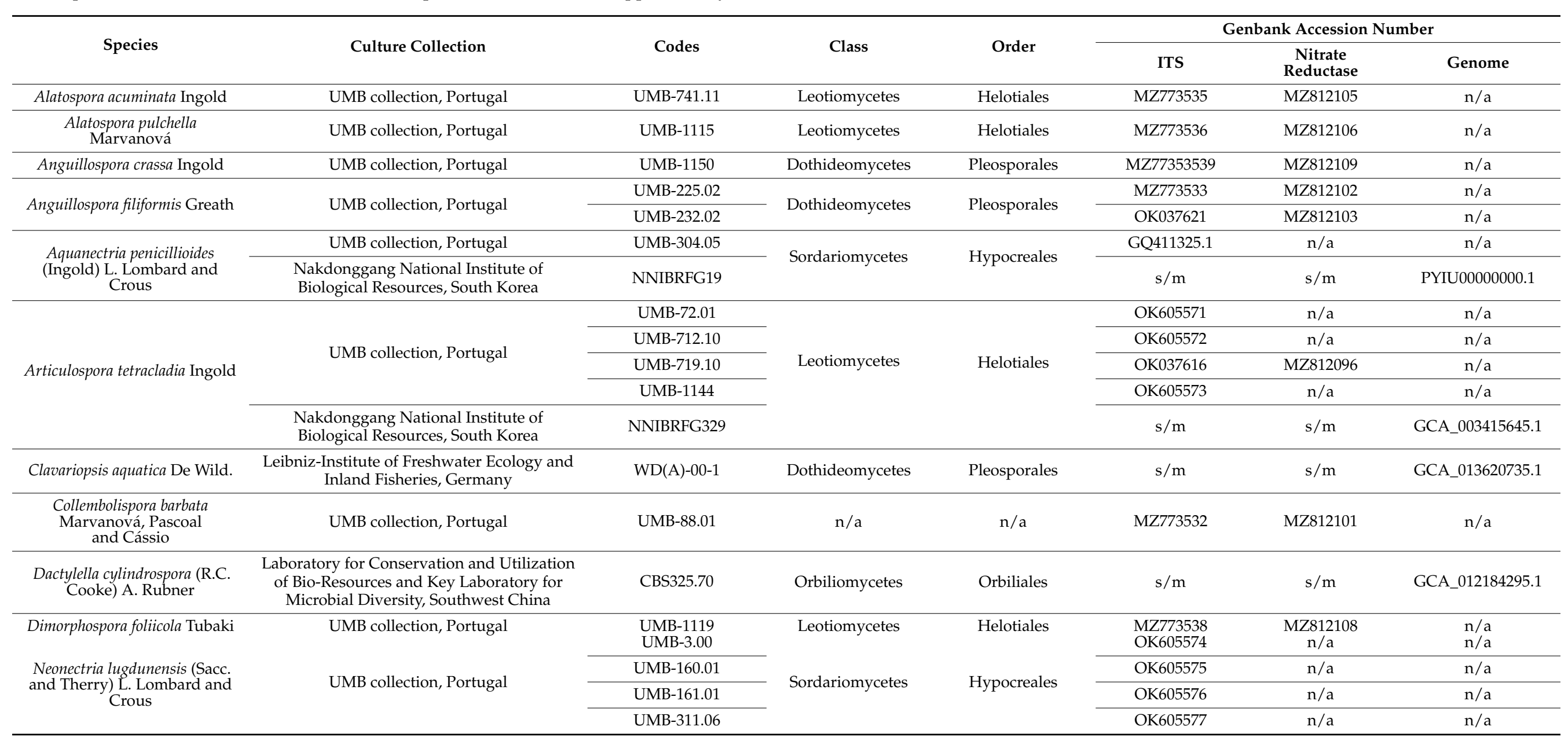


Table 1. Cont.

\begin{tabular}{|c|c|c|c|c|c|c|c|}
\hline \multirow{2}{*}{ Species } & \multirow{2}{*}{ Culture Collection } & \multirow{2}{*}{ Codes } & \multirow{2}{*}{ Class } & \multirow{2}{*}{ Order } & \multicolumn{3}{|c|}{ Genbank Accession Number } \\
\hline & & & & & ITS & $\begin{array}{c}\text { Nitrate } \\
\text { Reductase }\end{array}$ & Genome \\
\hline Lemonniera aquatica De Wild. & UMB collection, Portugal & UMB-594.10 & Leotiomycetes & Helotiales & MZ773530 & MZ812094 & $\mathrm{n} / \mathrm{a}$ \\
\hline Lunulospora curvula Ingold & UMB collection, Portugal & UMB-498.09 & $\mathrm{n} / \mathrm{a}$ & $\mathrm{n} / \mathrm{a}$ & OK605579 & $\mathrm{n} / \mathrm{a}$ & $\mathrm{n} / \mathrm{a}$ \\
\hline Margaritispora aquatica Ingold & $\begin{array}{l}\text { Nakdonggang National Institute of } \\
\text { Biological Resources, South Korea }\end{array}$ & NNIBRFG339 & Leotiomycetes & Helotiales & $\mathrm{s} / \mathrm{m}$ & $\mathrm{s} / \mathrm{m}$ & GCA_007644065.1 \\
\hline $\begin{array}{l}\text { Tetracladium apiense R.C. } \\
\text { Sinclair and Eicker }\end{array}$ & UMB collection, Portugal & UMB-535.10 & Leotiomycetes & Helotiales & OK037615 & MZ812093 & $\mathrm{n} / \mathrm{a}$ \\
\hline Tetracladium furcatum Descals & $\begin{array}{l}\text { Biology Dept., Mount Allison University, } \\
\text { Sackville, NB, Canada }\end{array}$ & F-11883 & Leotiomycetes & Helotiales & AF411026.1 & HQ234857.1 & $\mathrm{n} / \mathrm{a}$ \\
\hline \multirow{3}{*}{$\begin{array}{l}\text { Tetracladium marchalianum De } \\
\text { Wild. }\end{array}$} & \multirow{2}{*}{ UMB collection, Portugal } & UMB-1028.13 & \multirow{3}{*}{ Leotiomycetes } & \multirow{3}{*}{ Helotiales } & OK037619 & MZ812099 & $\mathrm{n} / \mathrm{a}$ \\
\hline & & UMB-1079.13 & & & OK037620 & MZ812100 & $\mathrm{n} / \mathrm{a}$ \\
\hline & $\begin{array}{l}\text { Biology Dept., Mount Allison University, } \\
\text { Sackville, NB, Canada }\end{array}$ & F-312 & & & AF411023.1 & HQ234858.1 & $\mathrm{n} / \mathrm{a}$ \\
\hline $\begin{array}{l}\text { Tetracladium maxilliforme } \\
\text { (Rostr.) Ingold }\end{array}$ & $\begin{array}{l}\text { Biology Dept., Mount Allison University, } \\
\text { Sackville, NB, Canada }\end{array}$ & F-14286 & Leotiomycetes & Helotiales & AF411027.1 & HQ234859.1 & $\mathrm{n} / \mathrm{a}$ \\
\hline $\begin{array}{l}\text { Tetracladium setigerum (Grove) } \\
\text { Ingold }\end{array}$ & $\begin{array}{l}\text { Institute for Environmental Sciences, } \\
\text { University of Koblenz-Landau, Germany }\end{array}$ & CCM F-20987 & Leotiomycetes & Helotiales & KU519120.1 & HQ234860.1 & $\mathrm{n} / \mathrm{a}$ \\
\hline $\begin{array}{l}\text { Thelonectria rubi (Osterw.) C. } \\
\text { Salgado \& P. Chaverri }\end{array}$ & $\begin{array}{l}\text { Agricultural Research Service, United States } \\
\text { Department of Agriculture, USA }\end{array}$ & CBS 177.27 & Sordariomycetes & Hypocreales & $\mathrm{s} / \mathrm{m}$ & $\mathrm{s} / \mathrm{m}$ & GCA_013420875.1 \\
\hline \multirow{2}{*}{ Tricladium chaetocladium Ingold } & \multirow{2}{*}{ UMB collection, Portugal } & UMB-904.12 & \multirow{2}{*}{ Leotiomycetes } & \multirow{2}{*}{ Helotiales } & OK037617 & MZ812097 & $\mathrm{n} / \mathrm{a}$ \\
\hline & & UMB-1116 & & & MZ773531 & MZ812095 & $\mathrm{n} / \mathrm{a}$ \\
\hline \multirow{3}{*}{ Tricladium splendens Ingold } & \multirow{3}{*}{ UMB collection, Portugal } & UMB-100.01 & \multirow{3}{*}{ Leotiomycetes } & \multirow{3}{*}{ Helotiales } & OK037618 & MZ812098 & $\mathrm{n} / \mathrm{a}$ \\
\hline & & UMB-414.09 & & & OK605580 & $\mathrm{n} / \mathrm{a}$ & $\mathrm{n} / \mathrm{a}$ \\
\hline & & UMB-1117 & & & MZ773537 & MZ812107 & $\mathrm{n} / \mathrm{a}$ \\
\hline \multirow{3}{*}{ Varicosporium elodeae W. Kegel } & \multirow{3}{*}{ UMB collection, Portugal } & UMB-310.06 & \multirow{3}{*}{ Leotiomycetes } & \multirow{3}{*}{ Helotiales } & OK605581 & $\mathrm{n} / \mathrm{a}$ & $\mathrm{n} / \mathrm{a}$ \\
\hline & & UMB-713.10 & & & MZ773534 & MZ812104 & $\mathrm{n} / \mathrm{a}$ \\
\hline & & UMB-878.12 & & & OK605582 & $\mathrm{n} / \mathrm{a}$ & $\mathrm{n} / \mathrm{a}$ \\
\hline
\end{tabular}




\subsection{Nitrate Reductase Gene Amplification}

A bibliographic search was made for primers targeting fungal genes potentially involved in nitrogen assimilation. The primers niaD01F/niaD04R and niaD15F/niaD12R successfully amplified the nitrate reductase gene euknr (partial sequence) from species of the genus Tetracladium [22]. For this reason, these primers were further explored in the present study. Resorting to Sequence Read Archive Nucleotide BLAST (SRABLASTn; https: / / BLAST.ncbi.nlm.nih.gov / BLAST.cgi; accessed on 3 February 2020), the selected primers were used as queries and located in the genomes of Articulospora tetracladia (SRX4652715), Margaritispora aquatica (SRX6454163) and Aquanectria penicillioides (SRX5023576), the only available aquatic hyphomycete genomes at the date of database accession, to evaluate the primers' compatibility with other aquatic hyphomycete species.

As the results displayed a considerable number of hits, these primers were selected to proceed with PCR amplification after optimization. Nested PCR was performed using the two sets of primers: niaD01F: $5^{\prime}$-GTNTGYGCNGGNAA-3' and niaD04R: $5^{\prime}$-GTNGGRTGYTCRAA-3' for the first amplification, targeting a wider region and niaD15F: $5^{\prime}$-GGNAAYMGNMGNAAR GARCARAA-3', niaD12R: 5'-AACCANGGRTTRTTCATCATNCC-3' for a more targetsequence-specific amplification using the products of the first amplification as a DNA template [22].

The optimal amplification conditions were as follows: $12.5 \mu \mathrm{L}$ of Accuzyme mix $(2 \times)$ (Bioline, London, UK), $2 \mu \mathrm{M}$ of each primer (niaD01F/niaD04R in the first PCR and niaD15F/niaD12R in the second PCR), $1.25 \mathrm{mM} \mathrm{MgCl} 2,20 \mu \mathrm{g} / \mu \mathrm{L}$ BSA, $1.25 \mu \mathrm{L}$ DMSO $(5 \%)$ and $2 \mu \mathrm{L}$ of DNA in a final volume of $25 \mu \mathrm{L}$. The cycling conditions were performed as described in Gorfer et al. (2011), using an iCycler Thermal Cycler (BioRad, Hercules, CA, USA). Negative controls with no DNA template were included in each batch. PCR success was assessed by gel electrophoresis (2\% agarose gels with $3 \%$ GreenSafe Premium (NZYtech, Lisbon, Portugal) run at $80 \mathrm{~V}$ for $75 \mathrm{~min}$ ), considering band(s) with $0.7-1 \mathrm{~kb}$ to potentially contain the nitrate reductase gene fragment [22]. PCR products were cleaned using Invitrogen's PureLink ${ }^{\circledR}$ PCR Purification Kit (Invitrogen Life Technologies, Carlsbad, CA, USA) according to manufacturer's protocol, and the DNA concentration was measured as above. The DNA was kept at $-20^{\circ} \mathrm{C}$.

\subsection{Cloning and Sequence Alignments}

Cloning of the PCR products was performed using NZY-blunt PCR cloning kit (Nzytech, Lisbon, Portugal) according to manufacturer's protocol. Eight clone colonies were selected from each cloning plate. Plasmids were extracted using NZYMiniprep (Nzytech, Lisbon, Portugal) according to manufacturer's protocol. For restriction digestion, the purified plasmid DNA was incubated overnight at $37^{\circ} \mathrm{C}$ with EcoRI or BamHI as follows: $2 \mu \mathrm{L}$ of DNA, $1 \mu \mathrm{L}$ of NZYSpeedyBuffer Colourless (NZYTech, Lisbon, Portugal) and $0.3 \mu \mathrm{L}$ of Speedy EcoRI/BamHI (NZYTech, Lisbon, Portugal) in a final volume of $10 \mu \mathrm{L}$. Enzyme inactivation was performed by incubating at $80^{\circ} \mathrm{C}$ for $20 \mathrm{~min}$.

DNA was run in an agarose gel to confirm the presence of the insert (expected size of approximately $1 \mathrm{~kb}$ ). Samples presenting bands meeting the expected band sizes were sequenced at STABVIDA (Caparica, Portugal), using the primers T7: 5'-AATACGACTCACTATAG-3' and U19mer: $5^{\prime}$-TTTTCCCAGTCACGACGT- $3^{\prime}$. Sequences were edited using the software BioEdit 7.2.5 [40] and Chromas (http://technelysium.com.au/wp/chromas/; accessed on the 2 March 2020). Forward and reverse sequences from each sample were first trimmed to remove the primers' binding sites T7 and U19mer and then aligned, with incongruences being manually corrected. Sequences were trimmed again to remove the EcoR V flanking regions.

After assessing the sequence orientations (due to blunt-end cloning), the last trimming was performed to remove the primers used to perform the PCR amplification (niaD15F and niaD12R). After this, all sequences were subjected to an individual BLASTn search, to evaluate whether they exhibited significant alignments with the targeted functional gene. Finally, multiple alignments were performed for the sequences obtained for each fungal strain in order to create a final consensus sequence. 
During this process, some sequences had to be discarded due to: (i) poor quality results in terms of sequencing, (ii) high differences from the other sample sequences for the same isolate, and (iii) not having relevant identity hits in the BLASTn platform sequence(s). The amount of sequences utilized for the final consensus alignments are presented in Table S2. Nitrate reductase partial nucleotide sequences obtained were deposited in GenBank (Accession numbers: MZ812093-109) (Table 1).

\subsection{In Silico Assays}

To the date of this analysis, six aquatic hyphomycete complete genomes were available at NCBI (www.ncbi.nlm.nih.gov/Genomes/; accessed on 30 October 2020), from whole genome shotgun sequencing projects: Articulospora tetracladia (NNIBRFG329), Aquanectria penicillioides (NNIBRFG19), Clavariopsis aquatica (WD(A)-00-1), Dactylella cylindrospora (CBS325.70), Margaritispora aquatica (NNIBRFG339), and Thelonectria rubi (CBS 177.27). Nevertheless, the genomes were not annotated yet.

We assessed the ITS sequences through primer (ITS1F and ITS4) search for all the six genomes, to confirm identities and establish taxonomic phylogenetic affiliations. The primers niaD15F and niaD12R, as well as a multiple alignment (using the MUSCLE tool from MEGA-X [41]) of our obtained consensus sequences were used to retrieve partial nitrate reductase sequences from all six genomes. Sequence trimming and analysis were performed in BioEdit 7.2.5 [40]. Nucleotide sequences for the ITS1-5.8S-ITS2 region and the nitrate reductase gene (partial sequences) were obtained for all six genomes.

\subsection{Phylogenetic Analysis}

After multiple alignment of the consensus sequences, the sequence divergence was analysed by using p-distance and the phylogenetic trees for the ITS1-5.8S-ITS2 region, and the nitrate reductase gene were generated with neighbour-joining (NJ) method [42] using Maximum composite likelihood distance model using MEGA X [41]. The positions containing alignment gaps and missing data were eliminated in pairwise sequence comparisons.

Branch support was evaluated using bootstrap analysis (1000 replicates [43]). Sequences from the terrestrial fungus Tilletiopsis washingtonensis (D_D11) (Basidiomycota, Exobasidiomycetes) were used as an outgroup to root the ITS1-5.8S-ITS2 (GenBank: HQ115649.1) and nitrate reductase partial nucleotide (GenBank: HQ234861.1) sequence trees. Phylogenetic trees were constructed and the percentage pairwise and overall mean distances were assessed using the same running options.

To estimate the evolutionary relationship between the ITS1-5.8S-ITS2 and the nitrate reductase nucleotide sequences, a Pearson correlation coefficient was calculated [44] using the pairwise distance matrices, considering interspecific variation (species-level average distances) and intraspecific (strain-level individual distances).

\section{Results}

\subsection{Evolutionary Taxonomic Divergence}

Fungal identification of 28 out of the 30 strains was confirmed by both conidial morphology (Figure S1) and ITS sequencing (Table 1). The strains Alatospora acuminata UMB-223.02, Neonectria lugdunensis UMB-161.01, Tetracladium marchalianum UMB-1079.13 and Tricladium splendens UMB-100.01 were identified based on molecular information only. The phylogenetic tree for the ITS1-5.8S-ITS2 region of aquatic hyphomycete strains is presented in Figure 1. 


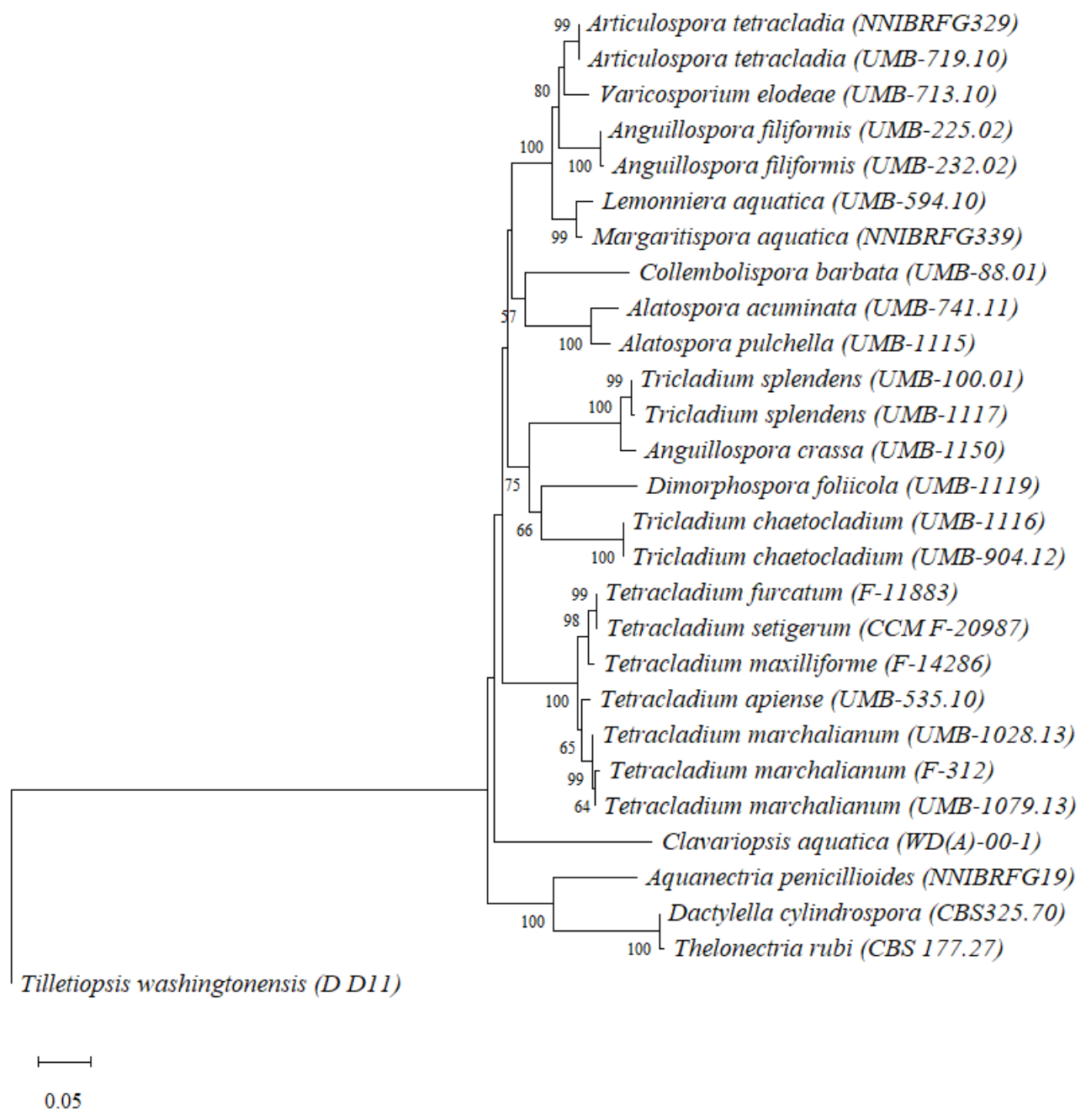

Figure 1. Neighbour joining tree based on ITS1-5.8S-ITS2 nucleotide sequences using Maximum composite likelihood distances. Numbers displayed at the nodes represent bootstrap values above $50 \%$, calculated from 1000 full heuristic replicates. The scale bar represents one base change per 100 nucleotide positions. Tilletiopsis washingtonensis (D_D11; Genbank code: HQ115649.1) was used as an outgroup.

Only species with a positive amplification of nitrate reductase gene (Table 2) were included in this analysis. The evolutionary divergences between aquatic hyphomycete species based on ITS-5.8S-ITS2 sequences ranged between 0 and $26.3 \pm 1.8 \%$ (Table S3), with an average sequence divergence of $16.6 \pm 0.9 \%$. Species from the genus Tricladium ( $T$. chaetocladium and T. splendens; $16.4 \pm 1.4 \%$ divergence) and Anguillospora (A. filiformis and A. crassa; $16.9 \pm 1.6 \%$ divergence) exhibited a higher interspecific divergence, grouping in different clades.

However, this was not the case for the genus Alatospora (A. acuminata and A. pulchella; $4.4 \pm 0.9 \%$ divergence) and Tetracladium (T. apiense, T. furcatum, T. marchalianum, T. maxilliforme and T. setigerum; $2.2 \pm 0.4 \%$ divergence), which were grouped within the same clade indicating a lower divergence. The lowest interspecific divergence (0) was found between Thelonectria rubi and Dactyllella cylindrospora, as well as between Tetracladium furcatum and Tetracladium setigerum. The highest divergence $(26.3 \pm 1.8 \%)$ was found for the pairs Clavariopsis aquatica/Dimorphospora foliicola and Clavariopsis aquatica/Thelonectria rubi. The intraspecific divergences ranged between 0 (Anguillospora filiformis, Tricladium chaetocladium and Tricladium splendens) and $0.2 \pm 0.2 \%$ (Articulospora tetracladia and Tetracladium marchalianum) (Table S4). 
Table 2. Amplification success of the nitrate reductase functional gene. Yes, successful amplification; and No, unsuccessful amplification.

\begin{tabular}{|c|c|c|}
\hline Species & Strain Code & $\begin{array}{c}\text { Nitrate Reductase } \\
\text { Amplification Success }\end{array}$ \\
\hline Alatospora acuminata & UMB-741.11 & Yes \\
\hline Alatospora pulchella & UMB-1115 & Yes \\
\hline Anguillospora crassa & UMB-217.02 & No \\
\hline Anguillospora crassa & UMB-1150 & Yes \\
\hline Anguillospora filiformis & UMB-225.02 & Yes \\
\hline Anguillospora filiformis & UMB-232.02 & Yes \\
\hline Aquanectria penicillioides & UMB-304.05 & No \\
\hline Articulospora tetracladia & UMB-72.01 & No \\
\hline Articulospora tetracladia & UMB-712.10 & Yes \\
\hline Articulospora tetracladia & UMB-719.10 & Yes \\
\hline Articulospora tetracladia & UMB-1144 & No \\
\hline Collembolispora barbata & UMB-88.01 & Yes \\
\hline Dimorphospora foliicola & UMB-1119 & Yes \\
\hline Lemonniera aquatica & UMB-594.10 & Yes \\
\hline Lunulospora curvula & UMB-108.01 & No \\
\hline Lunulospora curvula & UMB-498.09 & No \\
\hline Neonectria lugdunensis & UMB-3.00 & No \\
\hline Neonectria lugdunensis & UMB-160.01 & No \\
\hline Neonectria lugdunensis & UMB-161.01 & No \\
\hline Neonectria lugdunensis & UMB-311.06 & No \\
\hline Tetracladium apiense & UMB-535.10 & Yes \\
\hline Tetracladium marchalianum & UMB-1028.13 & Yes \\
\hline Tetracladium marchalianum & UMB-1079.13 & Yes \\
\hline Tricladium chaetocladium & UMB-904.12 & Yes \\
\hline Tricladium chaetocladium & UMB-1116 & Yes \\
\hline Tricladium splendens & UMB-100.01 & Yes \\
\hline Tricladium splendens & UMB-414.09 & No \\
\hline Tricladium splendens & UMB-1117 & Yes \\
\hline Varicosporium elodeae & UMB-310.06 & No \\
\hline Varicosporium elodeae & UMB-713.10 & Yes \\
\hline Varicosporium elodeae & UMB-878.12 & No \\
\hline \multicolumn{2}{|c|}{ Amplification success rate (\%) } & 58.1 \\
\hline
\end{tabular}

\subsection{Evolutionary Divergence of Nitrate Reductase Gene}

The amplification success for the nitrate reductase gene was 58.1\% (Table 2). Amplification within species exhibited one of three patterns: (i) successful amplifications for all strains (e.g., Anguillospora filiformis, Tetracladium marchalianum and Tricladium chaetocladium), (ii) variability between isolates, as some strains were successfully amplified and others were not (Anguillospora crassa, Articulospora tetracladia, Tricladium splendens and Varicospium elodeae) and (iii) no amplification for all strains (e.g., Neonectria lugdunensis and Lunulospora curvula). 
The eighteen successful amplifications (Table 2) were used for cloning and sequencing. The phylogenetic tree for the nitrate reductase sequences of aquatic hyphomycete strains showed that the evolutionary divergences between aquatic hyphomycete species ranged between 0 and $39.0 \pm 1.6 \%$ (Figure 2, Table S5) with an average sequence divergence of $26.4 \pm 0.9 \%$.

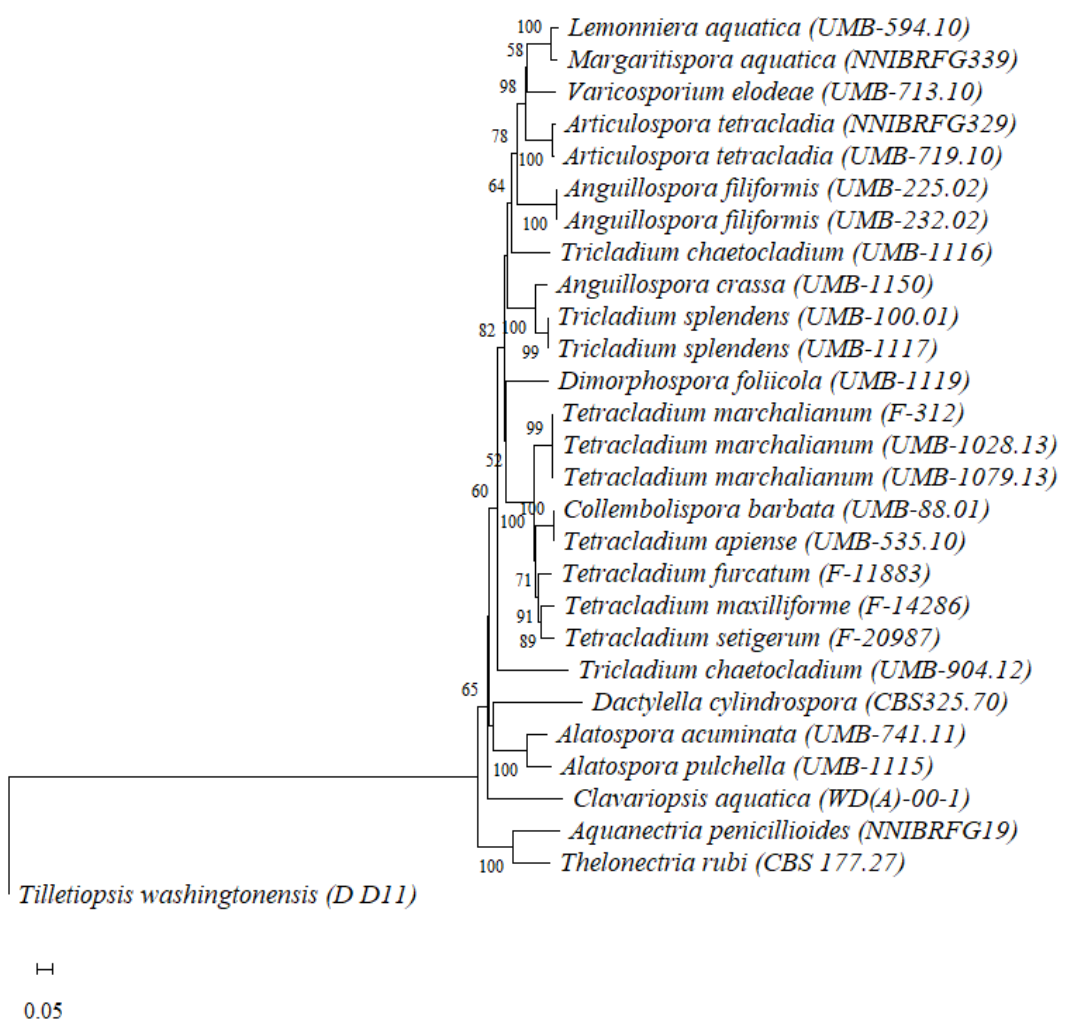

Figure 2. Neighbour joining tree based on nitrate reductase partial nucleotide sequences using Maximum composite likelihood distances. Numbers displayed at the notes represent bootstrap values above $50 \%$, calculated from 1000 full heuristic replicates. The scale bar represents one base change per 100 nucleotide positions. Tilletiopsis washingtonensis (D_D11; Genbank code: HQ234861.1) was used as an outgroup.

The species of the genus Anguillospora (A. crassa and A. filiformis), exhibited interspecific differences and were grouped in a separate clade (21.9 $\pm 1.4 \%$ divergence) (Table S5, Figure 2). Species of the genus Tricladium (T. chaetocladium and T. splendens) exhibited even higher evolutionary divergence between their partial nucleotide sequences $(26.5 \pm 1.2 \%)$, also grouping in different clades. Contrarily, species of the genus Tetracladium (T. apiense, T. furcatum, T. marchalianum, T. maxilliforme and T. setigerum) and Alatospora (A. acuminata and $A$. pulchella) exhibited closer phylogenetic relatedness and grouped in their own clades (divergence of $9.5 \pm 0.6 \%$ and $13.3 \pm 1.2 \%$, respectively; Table S5, Figure 2).

Other species showed a lower divergence: this was the case of Lemonniera aquatica and Margaritispora aquatica (divergence of $4.8 \pm 0.7 \%$ ) and the strains Tetracladium apiense UMB-535.10 and Collembolispora barbata UMB-88.01, which shared the same nucleotide sequence (0 sequence divergence). On the contrary, Aquanectria penicillioides and Dactylella cylindrospora exhibited the highest degree of divergence for the nitrate reductase gene $(39.0 \pm 1.6 \%)$.

The intraspecific evolutionary divergences ranged between 0 (for strains of Anguillospora filiformis and Tricladium splendens) and $30.0 \pm 1.5 \%$ (Tricladium chaetocladium strains), with intermediate values for strains of the species Tetracladium marchalianum and Articulospora tetracladia (Table S4). The highest intraspecific divergence was observed for Tricla- 
dium chaetocladium strains UMB-904.12 and UMB-1116, which were grouped in different clades (Figure 2).

\subsection{Relationship between Taxonomic and Functional Evolutionary Divergence}

A positive correlation was found between the evolutionary divergence of ITS1-5.8SITS2 region and the evolutionary divergence of the nitrate reductase gene of aquatic hyphomycetes species (Pearson-r $=0.77, p<0.0001$; Figure 3A). Notwithstanding, evolutionary divergences between some species did not follow this correlation. For instance, Dactylella cylindrospora and Thelonectria rubi were phylogenetically identical (0 divergence) but exhibited a divergence of $37.9 \pm 1.6 \%$ for the nitrate reductase gene. On the other hand, Collembolispora barbata and Tetracladium apiense, which exhibited an evolutionary divergence of $16.6 \pm 1.6 \%$ for the ITS1-5.8S-ITS2 region, displayed no divergence regarding the nitrate reductase gene.
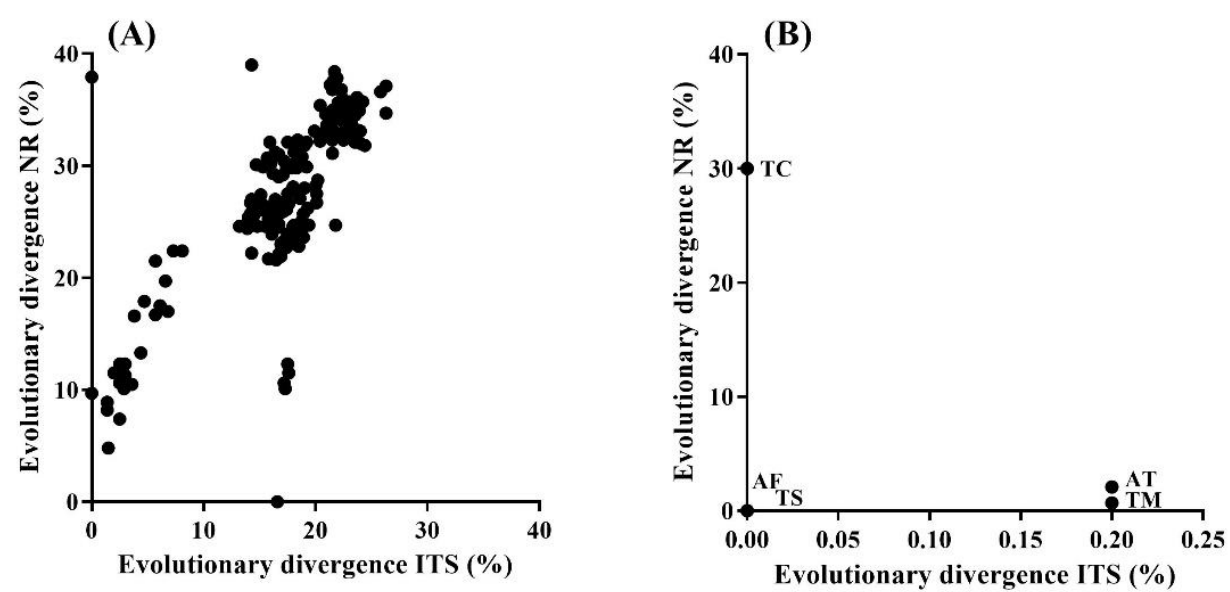

Figure 3. Pearson correlation between evolutionary divergence of ITS1-5.8S-ITS2 (ITS) and nitrate reductase (NR) sequences (A) between species (interspecific) and (B) within species (intraspecific). Evolutionary divergences were calculated as pairwise distances. AF-Anguillospora filiformis, ATArticulospora tetracladia, TM-Tetracladium marchalianum, TC-Tricladium chaetocladium, and TSTricladium splendens.

At the intraspecific level, no correlation was generally found between the evolutionary divergence of ITS1-5.8S-ITS2 region and the evolutionary divergence of the nitrate reductase gene (Pearson- $\mathrm{r}=-0.36, p=0.553$; Figure $3 \mathrm{~B}$ ). The only exceptions showing a positive correlation were Anguillospora filiformis and Tricladium splendens, but they presented evolutionary divergences of 0 for both ITS1-5.8S-ITS2 region and the nitrate reductase gene. Articulospora tetracladia and Tetracladium marchalianum exhibited low divergence $(<3 \%)$ for both ITS1-5.8S-ITS2 region and the nitrate reductase gene. Finally, Tricladium chaetocladium showed 0 evolutionary divergence for the ITS1-5.8S-ITS2 region, but a divergence of $30.0 \pm 1.5 \%$ was found for the nitrate reductase gene.

\section{Discussion}

The present study showed that there is inter- and intraspecific diversity in the nitrate reductase gene of aquatic hyphomycetes. In addition, our data showed a correlation between taxonomic (ITS1-5.8S-ITS2 region) and functional (nitrate reductase gene) divergence, supporting the hypothesis that fungal species that were phylogenetically closer exhibited higher functional gene relatedness. Recently, phylogeny was suggested to play a role in shaping the carbohydrate active enzyme and secondary metabolite content of genomes within Tetracladium genus [34]. As phylogenetic relatedness and similarities in functional diversity are expected to be correlated, functional gene analyses can provide new insights on fungal classification and species roles in ecosystem processes [45]. 
In this study, the ITS1-5.8S-ITS2 phylogenetic tree displayed a clade comprising Varicosporium elodeae, Articulospora tetracladia, Anguillospora filiformis, Lemonniera aquatica and Margaritispora aquatica, which have been previously observed to be closely related [32]. The results presented in the nitrate reductase phylogenetic tree reflected this close phylogenetic relatedness. We found that ITS1-5.8S-ITS2 and nitrate reductase phylogenetic trees exhibited relevant divergences between species of the genera Anguillospora (A. filiformis and A. crassa) and Tricladium (T. chaetocladium and T. splendens). The polyphyly of the genera Anguillospora and Tricladium is well documented, comprising anamorphs distributed among Dothideomycetes, Orbiliomycetes and Leotiomycetes [46-48]. On the contrary, all Tetracladium isolates (T. apiense, T. furcatum, T. marchalianum, T. maxilliforme and T. setigerum) were comprised in one clade in both ITS1-5.8S-ITS2 and nitrate reductase phylogenetic trees, which is supported by previous studies assessing phylogenetic [32] and nitrate reductase gene diversity [22] in this genus. These results are also sustained by the monophyly proposed for the Tetracladium genus (e.g., [49]). A close taxonomic relationship between Aquanectria penicillioides and Thelonectria rubi, which displayed one of the lowest divergences in ITS1-5.8S-ITS2 $(13.78 \pm 1.39 \%)$ and nitrate reductase gene $(22.38 \pm 1.37 \%)$, was found in our study, and this might be associated with the fact that these are the only species belonging to Hypocreales.

Even though a correlation between phylogeny and functional gene diversity was observed, there were some cases that did not fit this trend. This suggests that close taxonomic phylogenetic relatedness does not inherently translate into highly similar functional gene nucleotide sequences. Collembolispora barbata and Tetracladium apiense had identical nitrate reductase gene sequences, although they exhibited a high evolutionary divergence of the ITS1-5.8S-ITS2 region. Despite lacking a well-defined class, Collembolispora barbata grouped in the same branch of the ITS1-5.8S-ITS2 phylogenetic tree with both Alatospora isolates ( $A$. acuminata and A. pulchella). As Alatospora belongs to Leotiomycetes, this close relatedness suggests that this might be the class of Collembolispora barbata. However, further studies are necessary in order to confirm this hypothesis.

On the contrary, Dactylella cylindrospora and Thelonectria rubi were phylogenetically identical but exhibited a high divergence for the nitrate reductase gene. As Dactylella cylindrospora and Thelonectria rubi belong to two distinct classes (Orbiliales and Hypocreales, respectively), this degree of phylogenetic similarity was not expected. Gorfer and collaborators [22] found that most nitrate reductase sequences of soil fungi clustered according to their established phylogenies. Notwithstanding, some exceptions were found, like Doratomyces sp. (Microascales, Sordariomycetes), which did not cluster with the remaining strains from the Sordariomycetes class in the nitrate reductase gene tree [22].

Surprisingly, we found identical ITS1-5.8S-ITS2 sequences between the two strains of Tricladium chaetocladium; however, the degree of divergence for the nitrate reductase gene was above the average for the interspecific level. This indicates the existence of intraspecific functional diversity in aquatic hyphomycetes. Inter- and intraspecific variation was found in the number of carbohydrate binding modules and carbohydrate active enzyme domains between and within strains of the Tetracladium genus [34]. Previous studies have found intraspecific functional diversity among aquatic hyphomycetes from differently stressed [50-52] and undisturbed [53] environments. Although only two strains of Tricladium chaetocladium were used in our study, the results present a proof of concept for the existence of intraspecific genetic variability among aquatic hyphomycete species. Further studies with higher number of strains per species would enhance robustness and infer intraspecific variability in a clearer manner. In particular, it would be relevant to include in future analyses strains isolated from understudied regions like the tropics and the southern hemisphere [54]. This would certainly improve our understanding of the inter- and intraspecific variability of functional genes among aquatic hyphomycetes.

It is relevant to keep in mind that nucleotide sequence divergences do not represent the degree of divergence of their translated amino acid sequences. Due to the redundancy of the genetic code, distinct codons might codify for the same amino acid, meaning that 
inter- and intraspecific differences in the gene sequences might not necessarily translate into differences in the protein sequences. In order to confirm this, it would be important to retrieve complete nitrate reductase sequences to estimate full amino acid sequences and perform a comparative analysis.

Furthermore, it is relevant to highlight that the functional genetic information gathered in this study only provides insights for the functional potential of these organisms for the degradation of $\mathrm{N}$ compounds. Gene expression analysis would allow for a more accurate prediction of the active metabolism of each organism in ecosystems [55]. Nevertheless, approaches that allow this type of analysis, such as metatranscriptomics, are still very expensive and data-heavy. As there are only a limited number of aquatic hyphomycete genomes available, which are very sparsely annotated, attempting to identify functional gene expression without previous knowledge on the information encoded in that functional gene could constitute a major hardship. That said, the present study represents an important first step towards the understanding of functional diversity, making way for broader, more exciting approaches, such as metatranscriptomics, in investigations to come.

In our study, successful amplification of the nitrate reductase gene was obtained for $58.1 \%$ of the fungal strains. However, it is relevant to point out that the lack of amplification does not necessarily mean functional gene absence. Even though the primer pairs utilized were degenerate, they were designed based on terrestrial fungal species [22], which might be distinct from those of aquatic hyphomycetes. Mismatches between the fungal gDNA template and the primers (i.e., all the possibilities comprised by the degenerate primer) could result in a lack of amplification [56], even though the desired nucleotide sequences could still exist in the species genome. These factors must be taken into consideration before making assumptions about the inexistence of a particular functional gene and, consequently, the species functional abilities. Additionally, the design of primers specific to these organisms could potentially increase the amplification success rates but is limited by whole genome sequencing and annotation.

The recent publication of six aquatic hyphomycete whole genomes (Table 1) in public databases allowed complementing the results obtained in laboratory (with classical molecular techniques) by using in silico approaches to obtain nitrate reductase partial nucleotide sequences. This allowed increasing the diversity of fungal strains pool with the inclusion of new sequences from strains belonging to the classes Orbiliomycetes and Sordariomycetes. The 23 species utilized in our study belong to four classes: Orbiliomycetes, Sordariomycetes, Dothideomycetes and Leotiomycetes (Table 1). Yet, the majority of the strains used in our study $(60.9 \%)$ belong to Leotiomycetes, which is recognized as one of the most diverse classes of Ascomycota [57]. It would be important to expand this study by covering more species belonging to classes other than Leotiomycetes, in order to understand if the correlation between taxonomic and functional genetic diversity are kept when including species from different classes or even from different phyla (e.g., Basidiomycota). In addition, other early-diverging fungi present in aquatic systems, e.g., Chytridiomycota, can have an important role in organic matter decomposition [58] and thus this correlation should be tested in the future with other fungal groups.

Overall, a correlation between taxonomic and functional gene relatedness has been established for most species. The functional capabilities of each organism do not necessarily correspond to the enzymatic capabilities of a community comprising those organisms. Species interactions within a community are highly variable and context-dependent [59]. Factors, such as temperature, resources availability or stressors, have the ability to alter fungal biodiversity and ecosystem functioning in freshwater ecosystems [16,60,61].Even though the knowledge on fungal diversity and the genetic variation of functional genes is currently expanding, predictions of the potential ecological effects of single organisms combined with abiotic and biotic interactions, community dynamics and ecosystem functioning are still conjectural $[62,63]$. Establishing links between species' abilities to cope with environmental change for the maintenance of biogeochemical cycles and ecosystem functioning remains a challenge. Community gene expression analyses, such as metatran- 
scriptomics, have the potential to provide insights into community-level expression [55], which, for aquatic hyphomycetes, would be the first glimpses into their functional gene expression as a community. This approach would allow us to better link functional diversity to biogeochemical processes at an ecosystem scale [64]. Finally, the current study focused on the assimilatory nitrate reductase gene euknr [22]. To enable broader conclusions on the aquatic fungal contribution to the biogeochemical nitrogen cycle, the presence and diversity of dissimilatory nitrate reductase genes [65] should also be studied in the future.

Supplementary Materials: The following are available online at https: / www.mdpi.com/article / 10.3390/jof7121066/s1, Figure S1: Conidia of aquatic hyphomycetes. Table S1: ITS1-5.8S-ITS2 and Nitrate reductase DNA sequences retrieved from full genomes available in NCBI and referred in Table 1. Table S2: Number of clone colonies used for enzymatic restriction (EcoRI and BamHI), DNA inserts sent for sequencing and sequences utilized in the alignments of each fungal isolate (using all the sequencing efforts; both digestions with EcoRI and BamHI). Table S3: Evolutionary divergence $(\%)$ between aquatic hyphomycete species based on ITS-5.8S-ITS2 sequences. Table S4: Evolutionary divergence (\%) within aquatic hyphomycete species based on ITS-5.8S-ITS2 and Nitrate reductase sequences. Table S5: Evolutionary divergence (\%) between aquatic hyphomycete species based on nitrate reductase partial nucleotide sequences.

Author Contributions: Conceptualization, R.F.-D., F.C., C.P., I.F.; Methodology, J.M., R.F.-D., I.F.; Investigation, J.M., R.F.-D., I.F.; Writing-original draft preparation, J.M., R.F.-D., F.C., C.P., I.F.; Writing-review and editing, J.M., R.F.-D., F.C., C.P., I.F.; Funding acquisition, C.P. All authors have read and agreed to the published version of the manuscript.

Funding: This work was supported by the "Contrato-Programa" UIDB/04050/2020 funded by national funds through the Portuguese Foundation for Science and Technology (FCT) I.P and by the project STREAMECO-Biodiversity and eco-system functioning under climate change: from the gene to the stream: PTDC/CTA-AMB/31245/2017 funded by FCT.

Institutional Review Board Statement: Not applicable.

Informed Consent Statement: Not applicable.

Data Availability Statement: The data presented in this study are openly available in Genbank and Supplementary material. Genbank accession numbers are listed in Table 1.

Conflicts of Interest: The authors declare no conflict of interest. The funders had no role in the design of the study; in the collection, analyses, or interpretation of data; in the writing of the manuscript, or in the decision to publish the results.

\section{References}

1. Allan, J.D.; Castillo, M.M. Stream Ecology: Structure and Function of Running Waters, 2nd ed.; Springer: Dordrecht, The Netherlands, 2007; pp. 1-9.

2. Abelho, M. From litterfall to breakdown in streams: A review. Sci. World J. 2001, 1, 656-680. [CrossRef]

3. Graça, M.A.S.; Ferreira, V.; Canhoto, C.; Encalada, A.C.; Guerrero-Bolaño, F.; Wantzen, K.M.; Boyero, L. A conceptual model of litter breakdown in low order streams. Int. Rev. Hydrobiol. 2015, 100, 1-12. [CrossRef]

4. Marks, J.C. Revisiting the fates of dead leaves that fall into streams. Annu. Rev. Ecol. Evol. Syst. 2019, 50, 547-568. [CrossRef]

5. Gulis, V.; Suberkropp, K. Interactions between stream fungi and bacteria associated with decomposing leaf litter at different levels of nutrient availability. Aquat. Microb. Ecol. 2003, 30, 149-157. [CrossRef]

6. Pascoal, C.; Cássio, F. Contribution of fungi and bacteria to leaf litter decomposition in a polluted river. Appl. Environ. Microbiol. 2004, 70, 5266-5273. [CrossRef]

7. Das, M.; Royer, T.V.; Leff, L.G. Diversity of fungi, bacteria, and actinomycetes on leaves decomposing in a stream. Appl. Environ. Microbiol. 2007, 73, 756-767. [CrossRef]

8. Gessner, M.O.; Gulis, V.; Kuehn, K.A.; Chauvet, E.; Suberkropp, K. Fungal decomposers of plant litter in aquatic ecosystems. In Environmental and Microbial Relationships, 2nd ed.; Springer: Berlin/Heidelberg, Germany, 2007; pp. 301-324.

9. Chamier, A.-C. Cell-wall-degrading enzymes of aquatic hyphomycetes: A review. Bot. J. Linn. Soc. 1985, 91, 67-81. [CrossRef]

10. Zemek, J.; Marvanová, L.; Kuniak, L.; Kadleciková, B. Hydrolytic enzymes in aquatic hyphomycetes. Folia Microbiol. 1985, 30, 363-372. [CrossRef]

11. Cross, W.F.; Benstead, J.P.; Rosemond, A.D.; Wallace, J.B. Consumer-resource stoichiometry in detritus-based streams. Ecol. Lett. 2003, 6, 721-732. [CrossRef] 
12. Gulis, V.; Suberkropp, K.; Rosemond, A.D. Comparison of fungal activities on wood and leaf litter in unaltered and nutrientenriched headwater streams. Appl. Environ. Microbiol. 2008, 74, 1094-1101. [CrossRef]

13. Woodward, G.; Gessner, M.O.; Giller, P.S.; Gulis, V.; Hladyz, S.; Lecerf, A.; Malmqvist, B.; McKie, B.G.; Tiegs, S.D.; Cariss, H.; et al. Continental-scale effects of nutrient pollution on stream ecosystem functioning. Science (80-) 2012, 336, 1438-1440. [CrossRef]

14. Fernandes, I.; Seena, S.; Pascoal, C.; Cássio, F. Elevated temperature may intensify the positive effects of nutrients on microbial decomposition in streams. Freshw. Biol. 2014, 59, 2390-2399. [CrossRef]

15. Ferreira, V.; Castagneyrol, B.; Koricheva, J.; Gulis, V.; Chauvet, E.; Graça, M.A.S. A meta-analysis of the effects of nutrient enrichment on litter decomposition in streams. Biol. Rev. 2014, 90, 669-688. [CrossRef]

16. Pereira, A.; Geraldes, P.; Lima-Fernandes, E.; Fernandes, I.; Cássio, F.; Pascoal, C. Structural and functional measures of leaf-associated invertebrates and fungi as predictors of stream eutrophication. Ecol. Indic. 2016, 69, 648-656. [CrossRef]

17. Carpenter, S.R.; Caraco, N.F.; Correll, D.L.; Howarth, R.W.; Sharpley, A.N.; Smith, V.H. Nonpoint pollution of surface waters with phosphorus and nitrogen. Ecol. Appl. 1998, 8, 559-568. [CrossRef]

18. Melillo, J.M.; Naiman, R.J.; Aber, J.D.; Linkins, A.E. Factors controlling mass loss and nitrogen dynamics of plant litter decaying in northern streams. Bull. Mar. Sci. 1984, 35, 341-356.

19. Daniel-Vedele, F.; Filleur, S.; Caboche, M. Nitrate transport: A key step in nitrate assimilation. Physiol. Metab. 1998, 1, 235-239. [CrossRef]

20. Unkles, S.E.; Wang, R.; Wang, Y.; Glass, A.D.M.; Crawford, N.M.; Kinghorn, J.R. Nitrate reductase activity is required for nitrate uptake into fungal but not plant cells. J. Biol. Chem. 2004, 279, 28182-28186. [CrossRef]

21. Marcos, A.T.; Ramos, M.S.; Marcos, J.F.; Carmona, L.; Strauss, J.; Cánovas, D. Nitric oxide synthesis by nitrate reductase is regulated during development in Aspergillus. Mol. Microbiol. 2016, 99, 15-33. [CrossRef] [PubMed]

22. Gorfer, M.; Blumhoff, M.; Klaubauf, S.; Urban, A.; Inselsbacher, E.; Bandian, D.; Mitter, B.; Sessitsch, A.; Wanek, W.; Strauss, J. Community profiling and gene expression of fungal assimilatory nitrate reductases in agricultural soil. ISME J. 2011, 5, 1771-1783. [CrossRef]

23. Bärlocher, F.; Corkum, M. Nutrient enrichment overwhelms diversity effects in leaf decomposition by stream fungi. Oikos 2003, 101, 247-252. [CrossRef]

24. Duarte, S.; Pascoal, C.; Cássio, F.; Bärlocher, F. Aquatic hyphomycete diversity and identity affect leaf litter decomposition in microcosms. Oecologia 2006, 147, 658-666. [CrossRef]

25. Fernandes, I.; Pascoal, C.; Cássio, F. Intraspecific traits change biodiversity effects on ecosystem functioning under metal stress. Oecologia 2011, 166, 1019-1028. [CrossRef]

26. Dang, C.K.; Chauvet, E.; Gessner, M.O. Magnitude and variability of process rates in fungal diversity-litter decomposition relationships. Ecol. Lett. 2005, 8, 1129-1137. [CrossRef]

27. Geraldes, P.; Cássio, F.; Pascoal, C. Effects of increased temperature and aquatic fungal diversity on litter decomposition. Fungal Ecol. 2012, 5, 734-740. [CrossRef]

28. Andrade, R.; Pascoal, C.; Cássio, F. Effects of inter and intraspecific diversity and genetic divergence of aquatic fungal communities on leaf litter decomposition-a microcosm experiment. FEMS Microbiol. Ecol. 2016, 92, fiw102. [CrossRef] [PubMed]

29. Falkowski, P.G.; Fenchel, T.; Delong, E.F. The microbial engines that drive earth's biogeochemical cycles. Science (80-) 2008, 320, 1034-1039. [CrossRef] [PubMed]

30. Nikolcheva, L.G.; Bärlocher, F. Taxon-specific fungal primers reveal unexpectedly high diversity during leaf decomposition in a stream. Mycol. Prog. 2004, 3, 41-49. [CrossRef]

31. Seena, S.; Duarte, S.; Pascoal, C.; Cássio, F. Intraspecific variation of the aquatic fungus Articulospora tetracladia: An ubiquitous perspective. PLOS ONE 2012, 7, e35884.

32. Baschien, C.; Tsui, C.K.; Gulis, V.; Szewzyk, U.; Marvanová, L. The molecular phylogeny of aquatic hyphomycetes with affinity to the Leotiomycetes. Fungal Biol. 2013, 117, 660-672. [CrossRef]

33. Solé, M.; Müller, I.; Pecyna, M.J.; Fetzer, I.; Harms, H.; Schlossera, D. Differential regulation by organic compounds and heavy metals of multiple laccase genes in the aquatic hyphomycete Clavariopsis aquatica. Appl. Environ. Microbiol. 2012, 78, 4732-4739. [CrossRef]

34. Anderson, J.L.; Marvanová, L. Broad geographical and ecological diversity from similar genomic toolkits in the ascomycete genus Tetracladium. bioRxiv 2020, 1-33.

35. Bärlocher, F. Sporulation by aquatic hyphomycetes. In Methods to Study Litter Decomposition: A Practical Guide, 1st ed.; Graça, M.A.S., Bärlocher, F., Gessner, M.O., Eds.; Springer: Dordrecht, The Netherlands, 2005; pp. 185-188.

36. Gardes, M.; Bruns, T.D. ITS primers with enhanced specificity for basidiomycetes-Application to the identification of mycorrhizae and rusts. Mol. Ecol. 1993, 2, 113-118. [CrossRef]

37. White, T.J.; Bruns, T.D.; Lee, S.B.; Taylor, J.W. Analysis of phylogenetic relationship by amplification and direct sequencing of ribosimal RNA genes. In PCR Protocols: A Guide to Methods and Applications, 1st ed.; Innis, M.A., Gefland, D.H., Sninsky, J.J., White, T.J., Eds.; Academic Press: London, UK, 1990; pp. 315-322.

38. Duarte, S.; Seena, S.; Bärlocher, F.; Cássio, F.; Pascoal, C. Preliminary insights into the phylogeography of six aquatic hyphomycete species. PLoS ONE 2012, 7, e45289. [CrossRef] 
39. Nilsson, R.H.; Kristiansson, E.; Ryberg, M.; Hallenberg, N.; Larsson, K.-H. Intraspecific ITS variability in the kingdom fungi as expressed in the international sequence databases and its implications for molecular species identification. Evol. Bioinform. 2008, 4, 193-201. [CrossRef] [PubMed]

40. Hall, T.A. BioEdit: A user-friendly biological sequence alignment editor and analysis program for Windows 95/98/NT. Nucleic Acids Symp. Ser. 1999, 41, 95-98.

41. Kumar, S.; Stecher, G.; Li, M.; Knyaz, C.; Tamura, K. MEGA X: Molecular evolutionary genetics analysis across computing platforms. Mol. Biol. Evol. 2018, 35, 1547-1549. [CrossRef]

42. Saitou, N.; Nei, M. The neighbor-joining method: A new method for reconstructing phylogenetic trees. Mol. Biol. Evol. 1987, 4, 406-425.

43. Felsenstein, J. Confidence limits on phylogenies: An approach using the bootstrap. Evolution 1985, 39, 783-791. [CrossRef] [PubMed]

44. Wang, S.; Luo, X.; Wei, W.; Zheng, Y.; Dou, Y.; Cai, X. Calculation of evolutionary correlation between individual genes and full-length genome: A method useful for choosing phylogenetic markers for molecular epidemiology. PLoS ONE 2013, 8, e81106. [CrossRef] [PubMed]

45. Johnston, P.R.; Quijada, L.; Smith, C.A.; Baral, H.O.; Hosoya, T.; Baschien, C.; Pärtel, K.; Zhuang, W.Y.; Haelewaters, D.; Park, D.; et al. A multigene phylogeny toward a new phylogenetic classification of Leotiomycetes. IMA Fungus 2019, 10, 1-22. [CrossRef]

46. Belliveau, M.J.R.; Bärlocher, F. Molecular evidence confirms multiple origins of aquatic hyphomycetes. Mycol. Res. 2005, 109, 1407-1417. [CrossRef] [PubMed]

47. Baschien, C.; Marvanová, L.; Szewzyk, U. Phylogeny of selected aquatic hyphomycetes based on morphological and molecular data. Nov. Hedwig. 2006, 83, 311-352. [CrossRef]

48. Campbell, J.; Marvanová, L.; Gulis, V. Evolutionary relationships between aquatic anamorphs and teleomorphs: Tricladium and Varicosporium. Mycol. Res. 2009, 113, 1322-1334. [CrossRef] [PubMed]

49. Nikolcheva, L.G.; Bärlocher, F. Phylogeny of Tetracladium based on 18S rDNA. Czech Mycol. 2002, 53, 285-295. [CrossRef]

50. Miersch, J.; Grancharov, K. Cadmium and heat response of the fungus Heliscus lugdunensis isolated from highly polluted and unpolluted areas. Amino Acids 2008, 34, 271-277. [CrossRef] [PubMed]

51. Quainoo, S.; Seena, S.; Graça, M.A.S. Copper tolerant ecotypes of Heliscus lugdunensis differ in their ecological function and growth. Sci. Total Environ. 2016, 544, 168-174. [CrossRef] [PubMed]

52. Gonçalves, A.L.; Carvalho, A.; Bärlocher, F.; Canhoto, C. Are fungal strains from salinized streams adapted to salt-rich conditions? Philos. Trans. R. Soc. B Biol. Sci. 2019, 374, 20180018. [CrossRef] [PubMed]

53. Seena, S.; Casotti, C.; Cornut, J. Inter- and intraspecific functional variability of aquatic fungal decomposers and freshwater ecosystem processes. Sci. Total Environ. 2020, 707, 135570. [CrossRef]

54. Duarte, S.; Bärlocher, F.; Pascoal, C.; Cássio, F. Biogeography of aquatic hyphomycetes: Current knowledge and future perspectives. Fungal Ecol. 2016, 19, 169-181. [CrossRef]

55. Grossart, H.P.; Massana, R.; McMahon, K.D.; Walsh, D.A. Linking metagenomics to aquatic microbial ecology and biogeochemical cycles. Limnol. Oceanogr. 2020, 65, S2-S20. [CrossRef]

56. Green, S.J.; Venkatramanan, R.; Naqib, A. Deconstructing the polymerase chain reaction: Understanding and correcting bias associated with primer degeneracies and primer-template mismatches. PLoS ONE 2015, 10, e0128122. [CrossRef]

57. Baral, H.-O. Inoperculate discomycetes. In Syllabus of Plant Families: A. Engler's Syllabus der Pflanzenfamilien Part 1/2: Ascomycota; Jaklitsch, W., Baral, H.O., Lücking, R., Lumbsch, H.T., Frey, W., Eds.; Borntraeger: Stuttgar, Germany, 2016.

58. Gleason, F.H.; Kagami, M.; Lefevre, E.; Sime-Ngando, T. The ecology of chytrids in aquatic ecosystems: Roles in food web dynamics. Fungal Biol. Rev. 2008, 22, 17-25. [CrossRef]

59. Chamberlain, S.A.; Bronstein, J.L.; Rudgers, J.A. How context dependent are species interactions? Ecol. Lett. 2014, 17, 881-890. [CrossRef]

60. Jabiol, J.; Bruder, A.; Gessner, M.O.; Makkonen, M.; McKie, B.G.; Peeters, E.T.H.M.; Vos, V.C.A.; Chauvet, E. Diversity patterns of leaf-associated aquatic hyphomycetes along a broad latitudinal gradient. Fungal Ecol. 2013, 6, 439-448. [CrossRef]

61. Fernandes, I.; Pereira, A.; Trabulo, J.; Pascoal, C.; Cássio, F.; Duarte, S. Microscopy- or DNA-based analyses: Which methodology gives a truer picture of stream-dwelling decomposer fungal diversity? Fungal Ecol. 2015, 18, 130-134. [CrossRef]

62. Hughes, A.R.; Inouye, B.D.; Johnson, M.T.J.; Underwood, N.; Vellend, M. Ecological consequences of genetic diversity. Ecol. Lett. 2008, 11, 609-623. [CrossRef]

63. Graham, E.B.; Knelman, J.E.; Schindlbacher, A.; Siciliano, S.; Breulmann, M.; Yannarell, A.; Beman, J.M.; Abell, G.; Philippot, L.; Prosser, J.; et al. Microbes as engines of ecosystem function: When does community structure enhance predictions of ecosystem processes? Front. Microbiol. 2016, 7, 1-10. [CrossRef] [PubMed]

64. Linz, A.M.; Aylward, F.O.; Bertilsson, S.; McMahon, K.D. Time-series metatranscriptomes reveal conserved patterns between phototrophic and heterotrophic microbes in diverse freshwater systems. Limnol. Oceanogr. 2020, 65, S101-S112. [CrossRef]

65. Kamp, A.; Høgslund, S.; Risgaard-Petersen, N.; Stief, P. Nitrate storage and dissimilatory nitrate reduction by eukaryotic microbes. Front. Microbiol. 2015, 6, 1492. [CrossRef] 